\title{
CLINICAL CALORIMETRY
}

\author{
TWELFTH PAPER \\ THE METABOLISM OF BOYS 12 AND 13 YEARS OLD \\ COMPARED WITH THE METABOLISM AT \\ OTHER AGES *
}

\author{
EUGENE F. DU BOIS, M.D. \\ NEW YORK
}

In the period of development of boys, the years immediately preceding puberty are of especial interest. By this time the figure has lost most of its childish characteristics and the mind has reached a point of great intelligence. Although the individual has scarcely passed the half-way mark in the years of growth, and has only attained half his future weight, yet he resembles the adult much more than he resembles the infant. At this stage the sex glands have not yet begun the rapid development of puberty with its profound effect on the whole organism. Curiously enough there is a sudden increase in the rate of growth which takes place at this time. In fact, we may consider boys in the period of prepubescence as individuals of adult form but of small size, growing rapidly, and as yet scarcely influenced by the internal secretions of the sex glands. The study of their respiratory exchanges may throw light on many problems.

Recent developments in the science of metabolism have emphasized the necessity of using, for purposes of comparison, only those experiments in which the subjects were absolutely quiet. Since the assimilation of food increases the metabolism during four or five hours following a small meal, and five to ten hours after a large one, it is important to use only experiments in which this specific dynamic action is either slight or absent. The necessity for absolute quiet has long been recognized by Johansson and the Zuntz school, but has only been fully appreciated elsewhere for the last five years or so. The observations of Rubner ${ }^{1}$ and Sonden and Tigerstedt ${ }^{2}$ were made before this was understood, and the children were studied in large respiration chambers where they sat fairly quiet in chairs, eating from time to time, or else, as in the case of Rubner's boys, moving about the room at will. This

* Submitted for publication Feb. 4, 1916.

* From the Russell Sage Institute of Pathology, in Affiliation with the Second Medical Division of Bellevue Hospital.

1. Rubner: Beitrage zur Ernährung im Knabenaiter, Berlin, 1902.

2. Sonden and Tigerstedt: Untersuchungen über die Respiration und den Gesamtstoff wechsel des Menschen, Skand. Arch. f. Physiol., 1895, vi, 1. 
amount of activity might increase the metabolism anywhere from 10 to 30 per cent. above the resting value, and it is obvious that the results can be compared only with those obtained on other individuals who have shown exactly the same amount of muscular movement. It is for this reason that, while the careful work of the above mentioned observers is of great value in showing the changes during the different ages for a given amount of activity, it cannot be used in comparison with the experiments in which the subjects are quiet.

The classical study of Magnus-Levy and Falk ${ }^{3}$ established the fact that the metabolism is high during childhood and low after the onset of old age. These observers studied twenty-five children, twelve old men and women and twenty-five of intermediate ages. They used the Zuntz-Geppert apparatus, making several short experiments on each subject in the morning before breakfast, the individual lying at complete rest on a couch. It so happened that they included no boys between the ages of 11 and 14 in their list.

The metabolism during infancy has been well studied by Howland, ${ }^{4}$ Schlossmann and Murschhauser, ${ }^{5}$ Benedict and Talbot, ${ }^{6}$ Murlin and Hoobler, ${ }^{7}$ Bailey and Murlin ${ }^{8}$ and others, ${ }^{*}$ all of these observers paying especial attention to the question of muscular activity. On account of the difficulty of keeping infants quiet, Benedict and Talbot, and Murlin, Hoobler and Bailey were obliged to feed most of their subjects shortly before the experiment was started. It is quite possible that a lowering of metabolism during sleep may have. counterbalanced the slight increase due to the milk ingestion.

All of the above investigators have thrown new light on the subject. It would too greatly extend the bounds of this article to discuss in detail the several excellencies contained in their work. Of special interest is the fact that the metabolism of babies in the first month of life is

3. Magnus-Levy and Falk: Der Lungengaswechsel des Menschen in verschiedenen Alterstufen, Arch. f. Anat. u. Physiol., 1899, Supp1. 315.

4. Howland: Der Chemismus und Energieumsatz bei schlafenden Kindern, Ztschr. f. physiol. Chem., 1911, 1xxiv, 1.

5. Schlossman and Murschauser: For references see note 6.

6. Benedict and Talbot: The Gaseous Metabolism of Infants, Carnegie Institution of Washington, Pub. 201, 1914; Studies in the Respiratory Exchange of Infants, Am. Jour. Dis. Child., 1914, viii, 1.

7. Murlin and Hoobler: The Energy Metabolism of Ten Hospital Children, Am. Jour. Dis. Child., 1915, ix, 81.

8. Bailey and Murlin: The Energy Requirement of the New-Born, Am. Jour. Obst., 1915, 1xxi, 1.

* Just as this article is going to press Dr. Benedict has kindly called attention to the following reference: Olin: Carbon Dioxid Production in Boys of from 10 to 18 Years of Age; Finska Läksällsk: Handl Helsingfors, 1915, lvii, 1434. 
very low. This was apparently first discovered by Hasselbach, ${ }^{9}$ and later independently by Murlin, ${ }^{7}$ who first brought it to general attention. The same point was shown in Table 7 of Paper 4 of this series.

The metabolism of normal adults has been thoroughly studied in the last few years. Benedict, Emmes, Roth and Smith ${ }^{10}$ have collected 157 subjects, some of them as young as 15 years, using chiefly the Benedict universal respiration apparatus. Palmer, Means and Gamble, ${ }^{11}$ with the same instrument, have collected a considerable number of normal records and Means ${ }^{12}$ has recently calculated his results according to measurements taken by the new surface area formula described in Paper $5^{13}$ of this series. We have also at our command the normal controls of Paper $4^{14}$ and those of Papers 11 and 13, studied in the Sage calorimeter.

All of the above mentioned work on adults was done with very quiet subjects twelve or more hours after the last meal, and the technic of the observers was almost exactly the same. The results of these experiments have been charted in the accompanying curves, together with the work of Magnus-Levy and Falk, of Howland, Benedict and Talbot, Murlin and Hoobler, and Bailey and Murlin for comparison with the new results obtained on the boys 12 and 13 years old. Many other careful workers have studied the normal metabolism, but it has seemed best to use only the above mentioned investigations.

\section{METHOD OF EXPERIMENTS}

The Sage calorimeter and the methods employed in this research have been fully described in the previous papers of the series entitled Clinical Calorimetry. ${ }^{15}$ The surface area of the boys was determined according to the so-called "Linear Formula" described in Papers 5, 9 and 10 . The calories derived from protein were calculated from speci-

9. Hasselbach: Respirations-For $s \phi g$ Paa Nyf $\phi$ dte D $\phi r n$, Bibliot. f. Læeger, 1904, 8 de Række 5th Bind, 219.

10. Benedict, Emmes, Roth and Smith: The Basal, Gaseous Metabolism of Normal Men and Women, Jour. Biol Chem., 1914, xviii, 139. Benedict and Roth: The Metabolism of Vegetarians as Compared with the Metabolism of Non-Vegetarians of Like Weight and Height, Ibid, 1915, xx, 231. Benedict and Smith: The Metabolism of Athletes as Compared with Normal Individuals of Similar Height and Weight, Ibid, p. 243. Benedict and Emmes: A Comparison of the Basal Metabolism of Normal Men and Women, Ibid, p. 253. Benedict: Factors Affecting Basal Metabolism, Ibid, p. 263.

11. Palmer, Means and Gamble: Basal Metabolism and Creatinin Elimination, Jour. Biol. Chem., 1914, xix, 239.

12. Means: Basal Metabolism and Body Surface, Jour. Biol. Chem., 1915, $\mathrm{xxi}, 263$.

13. Clinical Calorimetry, Paper 5, The Archives Int. Med., 1915, xv. 868, 870.

14. Clinical Calorimetry, Paper 4, The Archives Int. Med., 1915, xv, 835.

15. Papers 1 to 8, The Archives Int. Med., 1915, xv, 793-945; Papers 9 to 17, Ibid., 1916, xvii, 855-1059. 
TABLE 1.-Results of Calorimeter-

\begin{tabular}{|c|c|c|c|c|c|c|c|c|c|}
\hline $\begin{array}{l}\text { Subject, } \\
\text { Date, } \\
\text { Weight, } \\
\text { Surface } \\
\text { Area, Linear } \\
\text { Formula }\end{array}$ & Period & $\begin{array}{c}\text { End } \\
\text { of } \\
\text { Period }\end{array}$ & $\begin{array}{c}\text { Carbon } \\
\text { Dioxid, } \\
\text { Gm. }\end{array}$ & $\begin{array}{c}\text { Oxygen, } \\
\text { Gm. }\end{array}$ & R. Q. & $\begin{array}{c}\text { Water, } \\
\text { Gm. }\end{array}$ & $\begin{array}{l}\text { Urine N } \\
\text { per } \\
\text { Hour, } \\
\text { Gm. }\end{array}$ & $\begin{array}{l}\text { Indirect } \\
\text { Calo- } \\
\text { rimetry, } \\
\text { Cal. }\end{array}$ & $\begin{array}{l}\text { Heat } \\
\text { Elimi- } \\
\text { nated, } \\
\text { Cal. }\end{array}$ \\
\hline \multirow{5}{*}{$\begin{array}{c}\text { F. R. S. } \ldots 73 \ldots \\
3 / 20 / 15 \\
32.09 \mathrm{Kg} . \\
1.124 \mathrm{Sq} . \mathrm{M} .\end{array}$} & Prelim. & $10: 57$ & ..... & $\ldots$. & $\ldots$. & $\ldots$. & $\cdots \cdot$ & ....... & $\ldots$. \\
\hline & 1 & $11: 57$ & 19.62 & 17.43 & 0.819 & 28.29 & 0.458 & 57.95 & 63.13 \\
\hline & 2 & $12: 57$ & 19.41 & 16.98 & 0.831 & 27.91 & 0.458 & 56.65 & 59.22 \\
\hline & 3 & $1: 57$ & 21.10 & 18.32 & 0.838 & 30.54 & 0.458 & 61.33 & 63.38 \\
\hline & & & & & & & & 175.93 & \\
\hline \multirow{4}{*}{$\begin{array}{c}\text { J. D. D. B. ....... } \\
3 / 26 / 15 \\
34.52 \mathrm{Kg} . \\
1.224 \text { Sq. M. }\end{array}$} & Prelim. & I1:01 & $\ldots .$. & $\ldots .$. & $\ldots \ldots$ & .... & .... & ...... & $\ldots .$. \\
\hline & 1 & $12: 01$ & 19.21 & 15.60 & 0.896 & 25.33 & 0.510 & 52.72 & 59.65 \\
\hline & 2 & $1: 01$ & 19.39 & 17.89 & 0.789 & 25.89 & 0.510 & 58.92 & 64.52 \\
\hline & & & & & & & & 111.64 & \\
\hline \multirow{4}{*}{$\begin{array}{c}\text { Raymond } \mathrm{M} . . . . \\
4 / 3 / 15 \\
30.41 \mathrm{Kg} . \\
1.084 \mathrm{Sq} . \mathrm{M} .\end{array}$} & Prelim. & $11: 14$ & ..... & $\ldots$. & $\ldots \ldots$ & $\ldots .$. & $\ldots .$. & ...... & ..... \\
\hline & 1 & $12: 14$ & 19.46 & 17.04 & 0.830 & 25.47 & 0.390 & 56.99 & 55.38 \\
\hline & 2 & $1: 14$ & 19.81 & 18.40 & 0.783 & 26.35 & 0.390 & 60.96 & 55.90 \\
\hline & & & & & & & & 117.95 & \\
\hline \multirow{4}{*}{$\begin{array}{c}\text { Reg. F. ........ } \\
4 / 5 / 15 \\
35.44 \mathrm{Kg} . \\
1.22 \mathrm{Sq.} \mathrm{M.}\end{array}$} & l'relim. & 11:01 & ..... & $\ldots$. & $\ldots \ldots$ & $\ldots .$. & $\cdots \cdot$ & ...... & $\cdots \cdot$. \\
\hline & 1 & 12:01 & 21.07 & 16.87 & 0.908 & 26.85 & 0.411 & 57.55 & 65.26 \\
\hline & 2 & $1: 06$ & 25.87 & 19.37 & 0.971 & 29.66 & 0.411 & 66.13 & 73.41 \\
\hline & & & & & & & & 123.68 & \\
\hline \multirow{4}{*}{$\begin{array}{c}\text { Harry B. ......... } \\
4 / 6 / 15 \\
36.57 \mathrm{Kg} . \\
1.232 \mathrm{Sq} . \mathbf{M} .\end{array}$} & Prelim. & $11: 05$ & $\ldots$. & $\ldots$. & $\ldots$. & $\ldots$. & $\ldots .$. & $\ldots .$. & $\ldots$. \\
\hline & 1 & $12: 05$ & 20.97 & 17.85 & $0.8 \overline{4}$ & 33.11 & 0.594 & 59.66 & 62.59 \\
\hline & 2 & $1: 05$ & 20.48 & 17.03 & 0.875 & 32.13 & 0.594 & 57.15 & 62.87 \\
\hline & & & & & & & & $\overline{116.81}$ & \\
\hline \multirow{4}{*}{$\begin{array}{c}\text { Henry } \mathbf{K} . \ldots . . . \\
4 / 7 / 15 \\
35.98 \mathrm{Kg} . \\
1.224 \mathrm{Sq} . \mathrm{M} .\end{array}$} & Prelim. & $11: 10$ & $\ldots .$. & $\ldots$. & $\ldots \ldots$ & $\cdots \cdot \cdot$ & $\cdots \cdot$ & ...... & $\cdots \cdots$ \\
\hline & 1 & $12: 10$ & 20.24 & 16.38 & 0.398 & 26.17 & 0.251 & 55.94 & 60.17 \\
\hline & 2 & $1: 10$ & 21.55 & 18.87 & 0.831 & 28.67 & 0.251 & 63.39 & 64.75 \\
\hline & & & & & & & & 119.33 & \\
\hline \multirow{4}{*}{$\begin{array}{c}\text { Arthur A. ....... } \\
4 / 8 / 15 \\
30.59 \mathrm{Kg} . \\
1.126 \mathrm{Sq} . \mathrm{M} .\end{array}$} & Prelim. & 11:13 & $\ldots .$. & .... & $\ldots$. & $\cdots \cdot$. & $\cdots \cdot$ & ...... & $\cdots \cdot$. \\
\hline & 1 & 12:13 & 17.57 & 17.01 & 0.751 & 21.74 & 0.308 & 55.84 & 59.51 \\
\hline & 2 & $1: 13$ & 18.64 & 16.97 & 0.799 & 21.58 & 0.308 & 56.46 & 58.32 \\
\hline & & & & & & & & 112.30 & \\
\hline \multirow{4}{*}{$\begin{array}{c}\text { Leslie } \mathrm{B} . \ldots \ldots \ldots \\
4 / 9 / 15 \\
28.53 \mathrm{Kg} . \\
1.050 \mathrm{Sq} . \mathbf{M} .\end{array}$} & Prelim. & $11: 15$ & $\cdots \cdot$ & $\ldots \ldots$ & $\ldots$. & $\ldots$. & $\cdots \cdot$. & ...... & $\cdots \cdot$ \\
\hline & 1 & $12: 15$ & 19.81 & 18.16 & 0.793 & 24.21 & 0.437 & 60.08 & 56.12 \\
\hline & 2 & $1: 15$ & 16.87 & 14.40 & 0.852 & 21.17 & 0.437 & 48.21 & 47.50 \\
\hline & & & & & & & & 108.29 & \\
\hline
\end{tabular}




\begin{tabular}{|c|c|c|c|c|c|c|c|c|c|c|}
\hline \multirow{2}{*}{$\begin{array}{c}\text { Direct } \\
\text { Calo- } \\
\text { rimetry } \\
\text { (Rectal } \\
\text { Temp.), } \\
\text { Cal. }\end{array}$} & \multirow{2}{*}{$\begin{array}{l}\text { Rectal } \\
\text { Temp., } \\
\text { C. }\end{array}$} & \multirow{2}{*}{$\begin{array}{l}\text { Aver- } \\
\text { age } \\
\text { Pulse }\end{array}$} & \multirow{2}{*}{$\begin{array}{l}\text { Work- } \\
\text { Adder, } \\
\text { Cm. }\end{array}$} & \multirow{2}{*}{$\begin{array}{l}\text { Non- } \\
\text { protein } \\
\text { R. Q. }\end{array}$} & \multicolumn{3}{|c|}{$\begin{array}{l}\text { Per Cent. } \\
\text { Calories from }\end{array}$} & \multicolumn{2}{|c|}{$\begin{array}{c}\text { Calories } \\
\text { per Hour }\end{array}$} & \multirow{2}{*}{ Remarks } \\
\hline & & & & & $\begin{array}{l}\text { Pro- } \\
\text { tein }\end{array}$ & Fat & $\begin{array}{c}\text { Carbo- } \\
\text { hyd. }\end{array}$ & $\begin{array}{l}\text { Per } \\
\text { Kg. }\end{array}$ & $\left|\begin{array}{c}\text { Per Sq. M. } \\
\text { (Meeh) }\end{array}\right|$ & \\
\hline$\ldots \ldots$ & 37.24 & .. & .. & $\ldots$ & .. & .. & .. & $\ldots$. & $\ldots$. & Basal \\
\hline 58.79 & 37.09 & 81 & 15 & 0.82 & 21 & 48 & 31 & 1.806 & 46.62 & \\
\hline 59.80 & 37.11 & 78 & 24 & 0.84 & 21 & 43 & 36 & 1.765 & 45.58 & \\
\hline$\frac{63.30}{181.89}$ & 37.13 & 80 & 34 & 0.85 & 20 & 41 & 39 & 1.911 & 49.34 & $\begin{array}{l}\text { Restless. Exclud } \\
\text { ed from basa } \\
\text { averages }\end{array}$ \\
\hline$\ldots \ldots$ & 37.56 & . & $\because$ & $\cdots$ & - & $\cdots$ & $\cdots$ & ..... & $\cdots \cdot$ & Basal \\
\hline 55.27 & 37.42 & 78 & 7 & 0.93 & 18 & 26 & 56 & 1.527 & 40.40 & \\
\hline 61.02 & 37.32 & 76 & 16 & 0.78 & 23 & 58 & 19 & 1.707 & 45.15 & \\
\hline 116.29 & & & & & & & & & & \\
\hline ...... & 36.83 & .. & .. & .... & .. & .. & .. & $\ldots$. & $\ldots .$. & Basal \\
\hline 54.63 & 36.90 & 83 & 5 & 0.84 & 18 & 45 & 37 & 1.874 & 47.49 & \\
\hline 56.54 & 37.21 & 87 & 12 & 0.78 & 17 & 62 & 21 & 2.005 & 50.80 & \\
\hline 111.17 & & & & & & & & & & \\
\hline ..... & 37.35 & . & .. & $\cdots$ & .. & $\cdots$ & •. & $\ldots$. & .... & Basal. \\
\hline 55.34 & 37.10 & 78 & 5 & 0.94 & 19 & 17 & 64 & 1.624 & 43.34 & \\
\hline 69.40 & 36.99 & 80 & 20 & 1.01 & 17 & 0 & 83 & 1.866 & 49.80 & \\
\hline 124.74 & & & & & & & & & & \\
\hline$\ldots \ldots$ & 37.30 & $\cdots$ & ・. & $\cdots \cdot$ & . & . & . & $\ldots$. & $\cdots \cdot$ & Basal \\
\hline 59.03 & 37.18 & 88 & 5 & 0.87 & 26 & 33 & 41 & 1.632 & 43.97 & \\
\hline 61.19 & 37.15 & 89 & 5 & 0.90 & 28 & 25 & 47 & 1.563 & 42.12 & \\
\hline 120.22 & & & & & & & & & & \\
\hline ...... & 37.02 & .. & .. & $\cdots$ & .. & .. & .. & ..... & ..... & Basal \\
\hline 51.77 & 36.74 & 88 & 5. & 0.91 & 12 & 27 & 61 & 1.555 & 41.65 & \\
\hline 67.20 & 36.83 & 87 & 7 & 0.83 & 11 & 52 & 37 & 1.762 & 47.20 & \\
\hline 118.97 & & & & & & & & & & \\
\hline ....... & 36.89 & .. & $\cdot \cdot$ & $\cdots$ & .. & .. & .. & $\cdots \cdot$ & $\cdots \cdots$ & Basal \\
\hline 54.24 & 36.69 & 81 & 11 & 0.74 & 15 & 75 & 10 & 1.825 & 46.38 & \\
\hline 58.88 & 36.72 & 82 & 4 & 0.80 & 14 & 58 & 28 & 1.846 & 46.89 & \\
\hline 113.12 & & & & & & & & & & \\
\hline$\ldots \ldots$ & 37.46 & .. &.. & $\cdots$ & .. & .. &.. & ..... & $\cdots .$. & Basal \\
\hline 55.40 & 37.44 & .. & 10 & 0.79 & 19 & 58 & 23. & 2.106 & 52.24 & \\
\hline 44.53 & 37.33 & 88 & 5 & 0.87 & 24 & 34 & 42 & 1.690 & 41.92 & \\
\hline 99.93 & & & & & & & & & & \\
\hline
\end{tabular}


mens voided between the hours of $9 \mathrm{a} . \mathrm{m}$. and $1: 15 \mathrm{p} . \mathrm{m}$. Twenty-four hour specimens could not be secured.

The subjects of the experiments here discussed were all healthy, normal boys between their twelfth and fourteenth birthdays. Two of them, F. R. S. and J. D. D. B., were related to members of the calorimeter staff, the others were Boy Scouts from one of the suburbs. A month or so before the research had been planned the writer had given the required physical examination to a group of sixteen Boy Scouts. The scout master selected as subjects for the experiments the five who most needed to earn money for uniforms. Harry B. was chosen because he was a patrol leader and able to manage the other boys. All the eight boys lived in the suburbs except J. D. D. B., who was home on a vacation from boarding school. They were all bright mentally and active physically, apparently being in constant motion when not studying or sleeping. The urine was examined in all cases and found to be normal.

In order to accustom the boys to the apparatus, they were brought to the calorimeter room a week or so before the experiment, sealed in the apparatus for a short time and trained in the simple routine. This was omitted in the case of F. R. S., who had helped his father build parts of the machine and was thoroughly familiar with the work. All of the boys considered the adventure as a lark and not one was apprehensive. A small breakfast, consisting of an egg, a slice of toast and a glass of milk, was allowed them at 7 o'clock, because it seemed probable that boys of this age would be ravenous and irritable if sent in from the country in a fasting condition.

The problem of keeping the youngsters quiet for three hours was hard to solve. It seemed best to allow them to read for one of the hours in a small book with large print. This proved satisfactory, the work involved in holding the book and turning the pages was very small. During the rest of the time the boys were bored. F. R. S. and J. D. D. B. remained quiet for two hours, but the former was so restless in the third period that experiments of this length were not attempted again. For the six Boy Scouts another expedient was tried. All the boys were anxious to earn pocket money and all were liberally paid for the experiments. A system of fines was instituted and the boys were told that one cent would be withheld for each centimeter that the work-adder tallied above 15 per hour. This figure was arbitrarily selected since it represents the average activity of a quiet subject who turns over once or twice an hour and shifts his position a few times is make himself comfortable. The boys took good care not to approach the danger mark. After the fine system was started the 15 centimeter mark was exceeded in only one period, and the lads as a group were the quietest of subjects. 


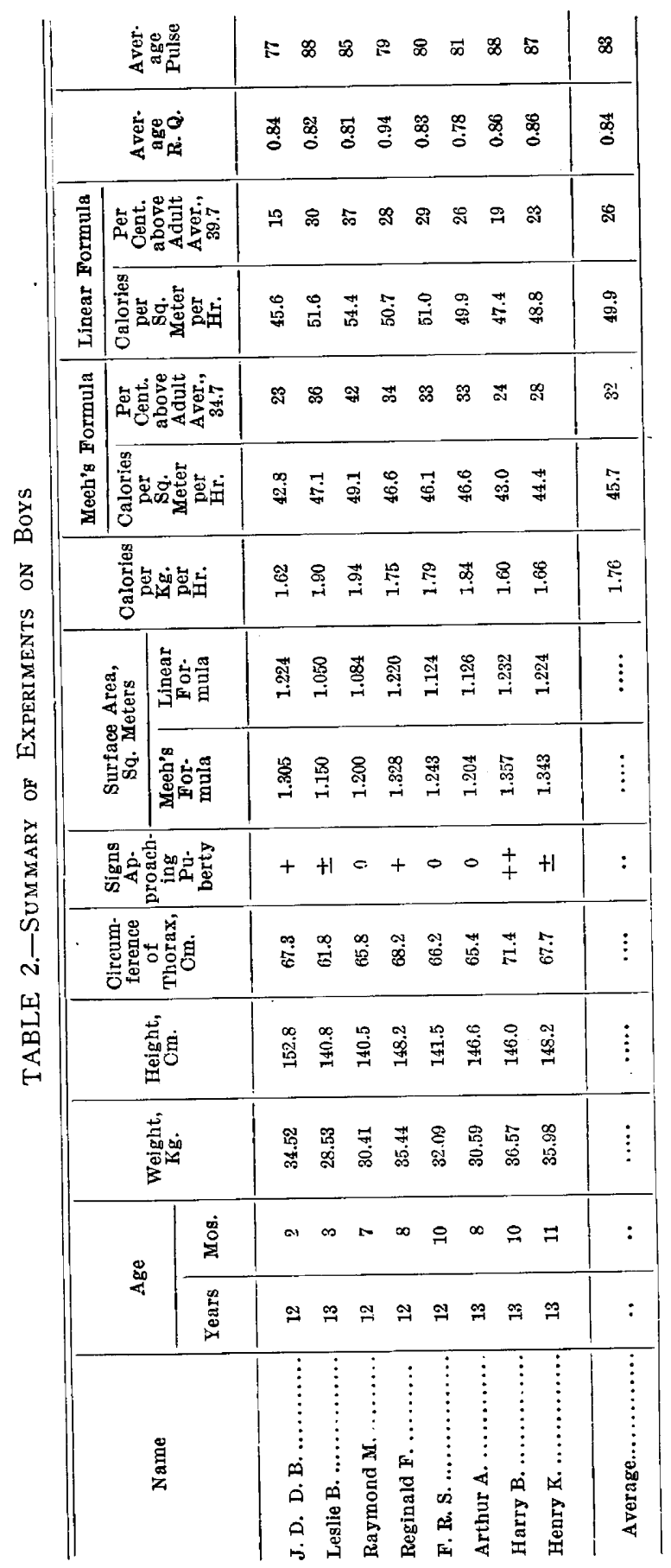


The question may be raised as to whether or not the breakfast taken by the subjects between 7 and $7: 30 \mathrm{a}$. $\mathrm{m}$. increased the metabolism between the hours of 11 and 1 o'clock. The standard meal allowed consisted of 1 egg, 1 glass of milk and 1 slice of toast with butter. They were shown standard portions of these and copied them as closely as possible, except Arthur A., who took nothing but 1 egg. The meal contained approximately $17 \mathrm{gm}$. of protein, 22 of fat and 30 of carbohydrate, with about enough calories to maintain a boy $51 / 2$ hours, if we allow an increase of 20 per cent. over the basal metabolism, to cover the journey to the hospital. J. D. D. B., who took his breakfast half an hour later than the others, had the lowest metabolism and Arthur A., who took the smallest breakfast, had almost the highest heat production. Mr. H. L. Higgins of the Nutrition Laboratory in Boston, kindly made a series of observations on a young man who took this same breakfast and found that the metabolism returned to its fasting level $31 / 2$ hours after the meal. It may perhaps be said that the metabolism was increased by the ride of fifty minutes in the train, ten minutes in the street cars and the walk of five minutes. The boys all reached the hospital by ten minutes past 9 , sat in a chair for three fourths of an hour, undressed and lay on the bed within the calorimeter at about 10 o'clock, the experiment beginning at 11 , or three and one half to four hours after breakfast. It will be noted that there was no significant drop in pulse rate or metabolism in the second periods. It is exceedingly doubtful if the combined increase due to the previous exercise, the specific dynamic action of food and the quiet reading amounted to 5 per cent. above the fasting level at absolute rest.

\section{DESCRIPTION OF SUBJECTS}

F. R. S., 12 years and 10 months old. He has been perfectly well except for one attack of abdominal pain in 1911, diagnosed as appendicitis.

Physical Examination.-Short, muscular and unustally well built; no signs of approaching puberty; disposition very active.

This boy was the son of the laboratory technician, who built and still operates the calorimeter, and he was thoroughly at home in his surroundings, having in fact helped to make the bed on which he lay. He was the only boy placed in the calorimeter for an experiment without previously staying for a short period in the apparatus. On the morning of the observation he took the standard breakfast at $6: 40 \mathrm{a} . \mathrm{m}$. While in the calorimeter he read quietly for the first hour. In the second hour he tried to sleep and was somewhat restless for part of the time. In the third hour he read for five minutes, and during the remainder of the time was so restless that this period has been excluded from the averages.

J. D. D. B., aged 12 years, 2 months. In 1911 he had measles; about six months prior to the experiment he suffered from a number of furuncles in the outer ear, and two weeks before the experiment had a cold in the head which lasted four days.

Physical Examination.-Very tall for his age, complexion dark, bones long and not heavy, very little subcutaneous fat, muscles sinewy; temperament rather 
high-strung but under good control; genitalia just beginning to develop; there were a few pubic hairs; voice not yet affected.

On the morning of the experiment he took the standard breakfast at 7:45 a. m., and came to the hospital in the street cars, being the only boy who lived in the city. In the first hour he was almost motionless and slept for a short time, and in the second period he read quietly in a small book.

Raymond M., aged 12 years, 7 months. He remembers that he had whooping cough as a baby and that he had measles two years previous to the experiment. $\mathrm{He}$ is short, stocky and muscular, but the thorax is rather narrow with a prominent sternum. His complexion is light and his disposition quiet. His physical examination is normal except that the right tonsil is moderately enlarged. He shows no signs of approaching puberty.

On the morning of the experiment he took the standard breakfast at $7: 30$ a. $\mathrm{m}$. During the first period he read very quietly and in the second period tried to sleep.

Reginald F., aged 12 years, 8 months. He remembers no illnesses except measles; he is tall, slim, of graceful build; his hair is brown; the pubic hair is just making its appearance and his voice suggests slight change; both mammary glands are palpable, measuring about 10 by $2 \mathrm{~mm}$. The left gland is slightly tender.

Standard breakfast at $7: 15$ a. $m$. In the first period he was very quiet, reading for twenty minutes. In the second period he slept for twenty minutes but was restless during the remainder of the time.

Harry B., aged 13 years, 10 months. Born in England; has been in this country eleven years; had measles in childhood and two weeks before the experiment was sick in bed a couple of days with stomachache. The day before he noticed a slight infection of his finger which pained him until it discharged a little pus. On the day of the experiment it did not hurt and he felt perfectly well.

Physical Examination.-Of moderate height and stocky muscular build, with broad shoulders; complexion fair. The left forefinger is red and slightly swollen near the nail, but there is no redness up the arm and no tenderness or swelling of the axillary nodes. The genitalia are approaching the adult type in development and there is a scant growth of pubic hair, and the mammmary glands are just palpable. The voice has not yet started to change.

He took the standard breakfast at 7:15 a. m. During the first hour he was awake but very quiet, and in the second hour he was also quiet, reading for thirty minutes.

Henry K., aged 13 years 11 months. Does not remember any illnesses except measles. $\mathrm{He}$ is tall, fairly muscular and well built except for the chest, which is narrow, with a prominent sternum. The upper jaw is narrow with high arch and prominent incisor teeth. His complexion is fair, his disposition quiet. The only sign of approaching puberty is a scant growth of pubic hair.

$\mathrm{He}$ ate the standard breakfast at 7 a. $\mathrm{m}$. In the first hour of the experiment he was practically motionless and in the second hour was very quiet, reading for fifty minutes.

Arthur A., aged 13 years, 8 months. Thinks he had measles and mumps when 3 or 4 years of age; three years prior to the experiment he broke his femur in a coasting accident. There is now no shortening of the limb. He is of slight, sinewy build with well formed chest, but gives the impression of being somewhat undernourished; complexion fair, disposition rather nervous; no signs of approaching puberty.

The evening before the experiment he was taken, with the other Boy Scouts, to an exhibition drill and in the excitement took no supper except one bun at $5 \mathrm{p} . \mathrm{m}$. On the morning of the observation in the calorimeter he ate nothing but an egg at $7 \mathrm{a} . \mathrm{m}$. He was very quiet both hours, reading forty minutes in the second period. 
Leslie B., brother of Harry B., aged 12 years, 3 months. In childhood he had measles and chickenpox. For the last few months he has had no appetite for breakfast and had suffered from stomachaches. He is of small frame, rather thin and undernourished but his color is good and his muscles strong. $\mathrm{His}$ complexion is fair and his disposition bashful and quiet. His teeth are in poor condition and his tonsils are enlarged. In the abdomen several masses of constipated feces are palpable. The only sign of approaching puberty is a scant growth of pubic hair.

On the morning of the experiment he took the standard breakfast at $7 \mathrm{a} . \mathrm{m}$. In the first period he was quiet, reading for forty-five minutes. In the second period he was unusually quiet, sleeping about three-quarters of the time. $\mathrm{He}$ was perfectly well until he came out of the calorimeter. He then felt faint, but recovered quickly.

\section{DISCUSSION OF RESULTS}

The total heat production in the eight experiments as measured by the method of indirect calorimetry was 985.93 calories, by the method of direct calorimetry 986.33 calories, a difference of 0.04 per cent.

A summary of the results obtained on the boys will be found in Table 2. It will be noted that the metabolism averaged 32 per cent. above the adult figure per unit of surface area according to Meeh's formula, or 25 per cent. above according to linear figure. The true significance of these results can be appreciated only if we consider the variations in the intensity of metabolism from birth to old age. It is for this reason that the results on normal individuals have been grouped in Charts 1 to 3 . The first (Chart 1) represents the metabolism from birth to the age of 24 calculated per kilogram of body weight. It will be noted in general that the heat production of the infants shows wide variations, but at a much higher level than that of the adults. A uniform decrease in the metabolism becomes evident after the sixth year, becoming less marked after the twentieth year. In Paper 4 of this series we have mentioned the disadvantages of using the body weight as a basis of comparison of individuals of different sizes. Small animals show per kilogram a calorific production so much greater than that of large animals that it is almost a waste of time to compare children and adults by using this standard. For clinical purposes, however, the body weight is a convenient guide.

Chart 2 shows the metabolism from birth to the age of 24 expressed in terms of calories per square meter of body surface as determined by Meeh's formula. Lines have been drawn showing as nearly as possible the averages for males and females. It will be seen that the metabolism is low at birth, increases rapidly during the first year, reaches its maximum in the almost unexplored period between the ages of 1 and 6 , falls quite rapidly until the age of 20 , then very slowly. During infancy there is no apparent difference between the sexes, but after the age of 6 the girls and women have a distinctly lower metabolism. 




Chart 1.-Variation of basal metabolism with age: Calories per hour per kilogram of body weight. 
In Papers 4 and 5 we have shown the reasons for preferring the calories per unit of surface area as a guide for the intensity of the metabolism, and have also shown the errors and limitations of Meeh's formula which has been the standard for so many years. The fact that the formula shows an average plus error of 16 per cent. scarcely affects its value for purposes of comparison with subjects of usual build. On the other hand, the tendency of this error to be much smaller in the case of thin subjects and larger in the case of fat ones, is of considerable importance. New-born infants are relatively thin, older children relatively chubby until the age of 4 or 5 , when they grow taller and thinner until puberty. Women tend to put on weight after 30 and men do so five or ten years later. If, therefore, we try to correct the curve for these errors in Meeh's formula we find that the peak in early childhood will be accentuated and the rest of the curve flattened out.

Chart 3 gives the results for males expressed in terms of calories per square meter of body surface as determined by the new so-called "Linear Formula." It will be seen that the metabolism of the adults is somewhat more uniform and that the boys average only 25 per cent. above the adult level instead of 32 per cent. as in the previous chart. This indicates a true increase of 25 per cent. above the heat production which a group of normal adults would show if they were the same size as the boys. For purposes of comparison the metabolism of the infants has been recorded in terms of Lissauer's Formula. ${ }^{13}$

When we consider the question of the metabolism in the first year or so of life we must remember that the infant differs greatly from the adult in the proportions of the body and the relative size of the various organs. A baby $51 / 2$ feet tall would be a short legged, long bodied monster with an enormous head. He would have a very large liver and a comparatively large thyroid gland. At birth the liver comprises 4.5 per cent. of the body weight and during adult life less than 3 per cent. Since this is supposed to be a gland of high metabolic activity, one would naturally expect an increased heat production in an organism with a relatively large liver. Still more important in regulating metabolism is the thyroid gland, which is considered to be three times as large in the new-born as in the adult, although recent measurements by Parski makes the figures somewhat smalier. Thyroid secretion has such a marked effect on development that it is quite possible that the gland is relatively more active in childhood. Some might even argue that the increased metabolism of this period is in itself evidence of a greater activity of the thyroid. Such a theory would be unwarranted unless supported by a greater number of facts than are now available. It should be remembered that the phenomena of growth are not so very different with invertebrates which have no thyroids. 


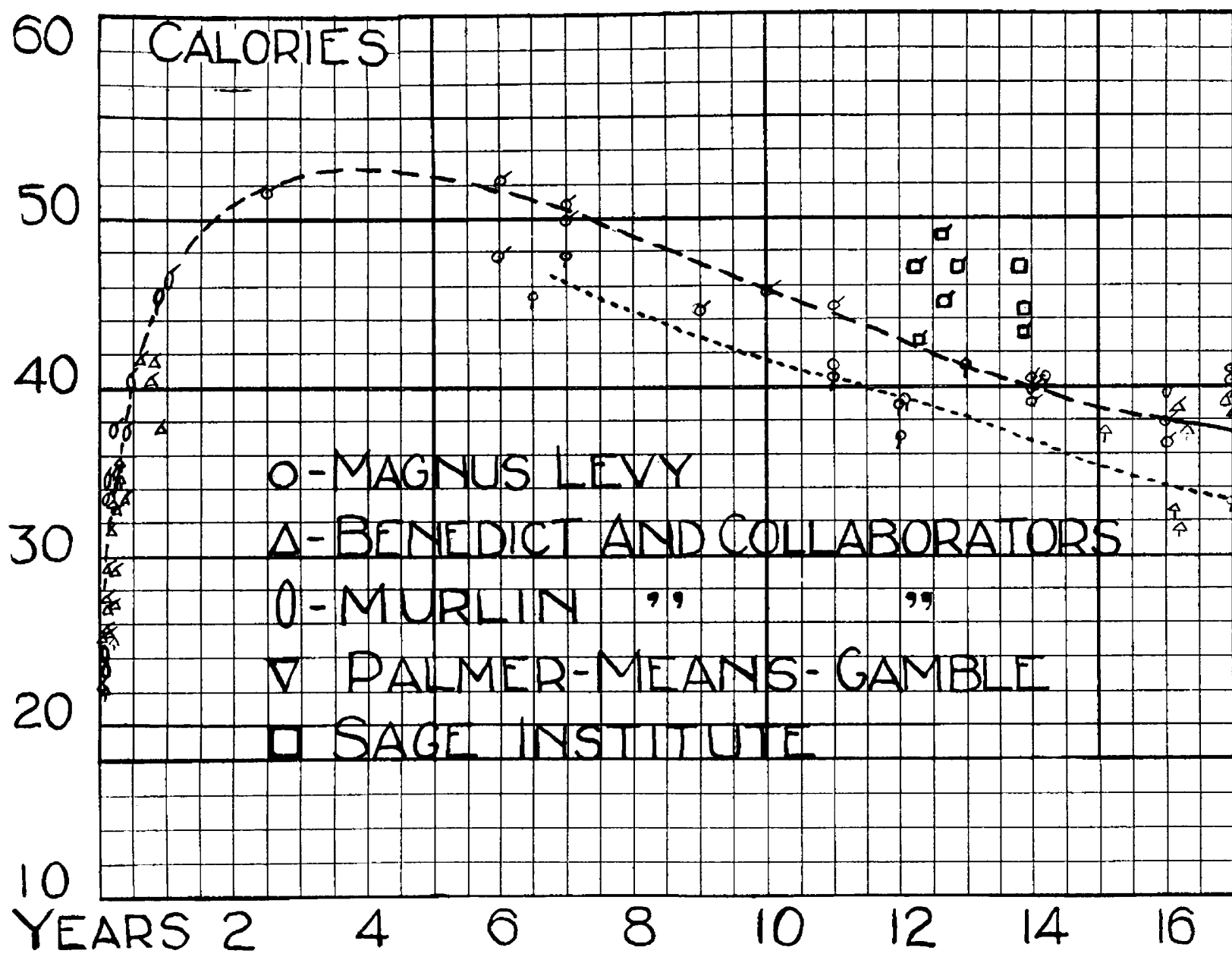

Chart 2.-Variations of basal metabolism with age: Calories per hour per square meter of body Dash line shows average for males, dotted line for females. 




asal metabolism with age: Calories per hour per square meter of body surface-Mech's formula.

noch lins clowe averace for males fonteral line for females 
Variation Of Basal Metabolism With age.

Cal PER HOUR PER SQ METER OF BOdY SURFACE-Linear formula

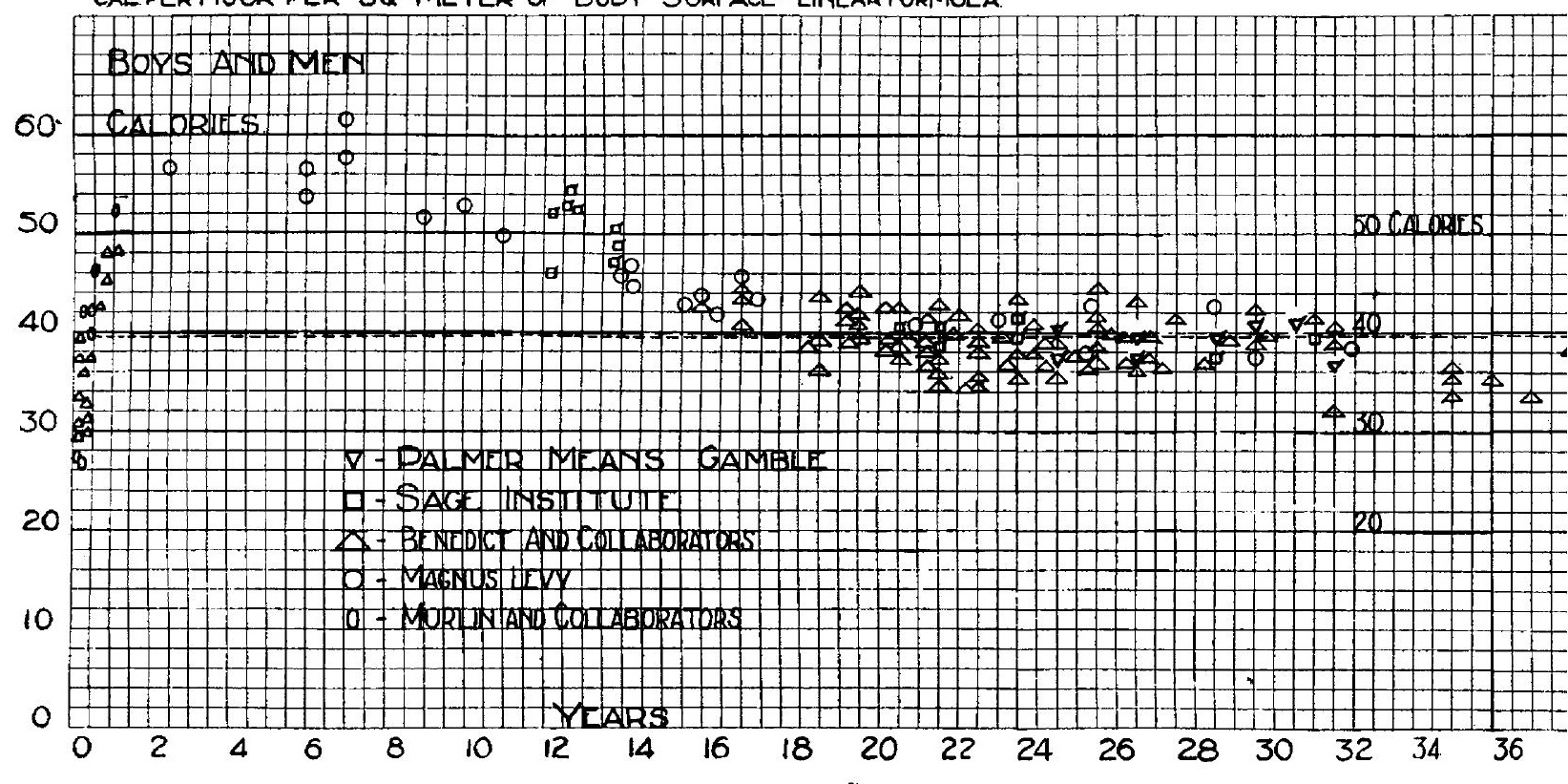

Chart 3.-Variation of basal metabolism with age; C 
'ITH AGE

NEAR FORMULA.

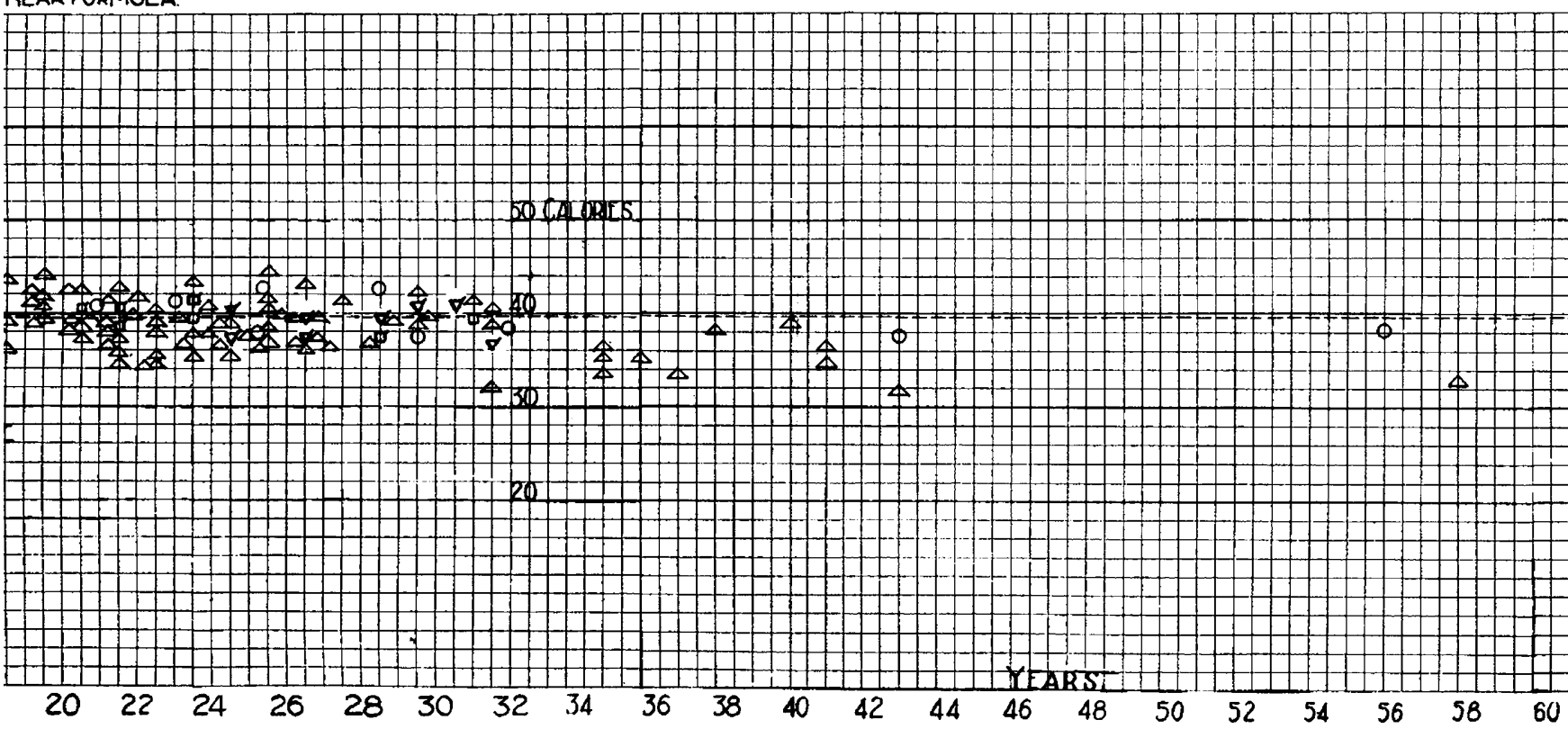

Chart 3.-Variation of basal metabolism with age; Calories per hour per square meter of body surface-Linear formula. 


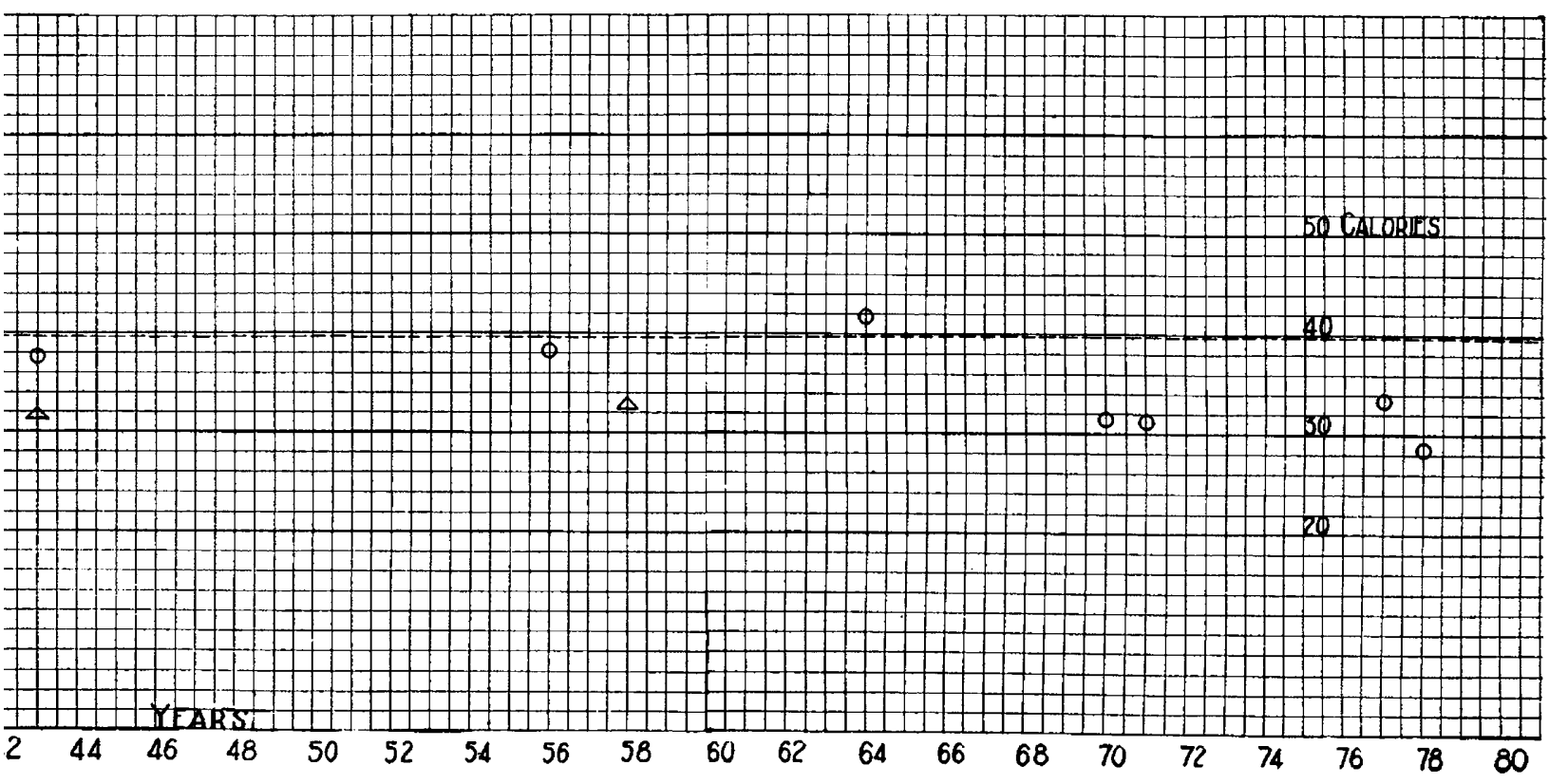

our per square meter of body surface-Linear formula. 
The Sage calorimeter has recently been able to throw an interesting sidelight on the relationship of body form to metabolism. Two men who in youth had lost both legs in accidents, were studied in the respiration chamber and the surface area determined by formula and actual measurement. The one who was fat showed a metabolism only 4 per cent. above the normal average; the one who was muscular was 2 or 3 per cent. above. These men resembled infants in the relative proportion of body to extremities. This indicates that the law of surface area holds true under dissimilar physiological conditions such as are found in legless men. The high metabolism of infants is not therefore, due to the differences in body shape and body composition.

These factors are almost entirely ruled out in the case of the boys 12 and 13 years old. At this age the body has assumed almost the adult proportions and the liver and thyroid are not much larger in proportion to the body weight than in later life. The metabolism of these boys is very much higher than that of adults. It is rather a striking fact that the metabolism was distinctly higher in the boys who showed no signs of approaching puberty than in those who showed traces of pubic hair and increasing development of the genitalia. It is hoped that the same group of boys can be studied at intervals during pubescence. These boys can be compared with the case of infantilism studied by McCrudden and Lusk in the calorimeter of the Department of Physiology of the Cornell Medical College. This dwarf, who was 17 years old, and about the size of an average boy of 6 years, showed a metabolism of 23.3 calories per hour per square meter (Meeh), which was 7 per cent. below the adult normal average.

The growth of children in length and weight is very rapid during the first two years of life and then decreases somewhat between the ages of 8 and 12. Following this is a period of increased growth, with relatively greater gain in stature than in weight. This begins in almost all the nations at the age of 12 or 13 in boys and reaches its height between the thirteenth and fifteenth years. The figures of Boas ${ }^{16}$ and Burk $^{17}$ are well worth consulting, and Wiener's ${ }^{18}$ measurements of three of his sons show this increase in the period of prepubescence very clearly. The curve of weight is somewhat different, since boys become relatively thinner as they grow tall and do not fill out again

16. Boas: The Growth of Toronto Children, Report U. S. Commr. Education, 1896-97, ii, 1541.

17. Burk: Growth of Children in Height and Weight, Am. Jour. Psychol., $1898, \mathrm{ix}, 253$.

18. Wiener: Das Wachstum des menschlichen Körpers, Karlsruhe, 1890.

Chart reproduced in Burk's paper (note 17) and also in Hall's Adolescence, New York, 1904. 
until puberty is well established. In the case of girls the period of increasing growth comes a year or two earlier.

In adult life the nearest approach to the growth of childhood is found in the period of convalescence from acute infectious diseases. The fact that the metabolism is increased at such times was demonstrated by Svenson, Rolly and others. Coleman and Du Bois ${ }^{19}$ have shown that after typhoid the metabolism which falls to normal at the end of the fever, may rise to an average of 17 per cent. above normal in the second and third weeks of convalescence. It is significant that the body which is repairing the losses of protein and fat during the fever should be maintaining its metabolism at a level which approaches that found in childhood. It is also significant that a second peak in the curve representing the heat production at different ages is found in the case of these boys just at the period of a renewed increase in the rate of growth. The evidence points toward a specific increase in the metabolism of the growing organism.

There is no apparent explanation for the fact that the metabolism was higher in the boys who showed no signs of approaching puberty than in the others. It is difficult to explain the low metabolism of newborn infants. It must be considered, however, that the unborn baby is essentially similar to an internal organ which is practically free from the play of external physical stimuli. Under such conditions the heat production must be on a different level from that in later life after a fuller development of the neuromuscular elements has been completed.

\section{SUMMARY AND CONCLUSIONS}

Eight normal boys, 12 or 13 years old, were studied in the respiration calorimeter four to six hours after a small breakfast. They were allowed to read for one of the two experimental hours, but were very quiet. The methods of direct and indirect calorimetry agreed within 0.04 per cent. Their heat production per unit of surface area was 32 per cent. higher than the adult level according to Meeh's formula, or 25 per cent. higher according to the more accurate "Linear Formula."

In studying the effect of growth on metabolism, interpretation of the results obtained on infants is complicated by the fact that babies differ greatly from adults in the proportions of the body and the relative size of the viscera, notably the liver and thyroid. Boys just before the onset of puberty have almost adult proportions. They are in the midst

19. Coleman and Du Bois: The Influence of the High Calory Diet on the Respiratory Exchanges in Typhoid Fever, The Archives Inr. Med., 1914, xiv., 168; also Clinical Calorimetry, Paper 7, ibid., 1915, xv., 887. 
of a period of accelerated growth. The fact that the metabolism is high, points to a specific increase in the metabolism of the growing organism.

The writer wishes to thank those whose assistance made this research possible. The electrical measurements were made by Mr. F. G. Soderstrom, the residual analyses and calculations by Dr. A. L. Meyer and the calculations were checked by Miss Grace Sims. Urinalyses were made by Mr. F. C. Gephart and Mr, R. $\mathrm{H}$. Stone. 